\title{
IMPLEMENTING INNOVATIONS IN CHEMISTRY LEARNING AND SUSTAINABILITY EDUCATION IN A NON-FORMAL STUDENT LABORATORY CONTEXT
}

\author{
Nicole Garner ${ }^{1}$, Antje Siol${ }^{2}$, Johannes Huwer ${ }^{3}$, Rolf Hempelmann³ \& Ingo Eilks ${ }^{1}$ \\ ${ }^{1}$ Institute of Science Education (IDN) - Chemistry Education Group, University of Bremen, Germany \\ ${ }^{2}$ Center for Environmental Research and Sustainable Technology (UFT), University of Bremen, \\ Germany \\ 3Physical Chemistry, Saarland University, Saarbrücken, Germany
}

\begin{abstract}
Informal and non-formal science education became major trends in many countries in recent years. Non-formal learning was suggested to help closing gaps in science education, e.g. by providing students an alternative environment to experience practical work. Non-formal education was also suggested to offer a chance for curriculum innovations and teacher continuous professional development. One potential field might be Education for Sustainable Development (ESD). Several perspective papers in recent years described that secondary chemistry education is still lacking in implementing education for sustainability and learning about green chemistry. This article describes the project "Sustainability and chemistry in non-formal student laboratories" that was initiated to develop non-formal learning environments to help implementation of ESD and learning about green chemistry. This article presents the goals and structure of the project, including an example taken from practical experience and selected findings from implementing the proposed non-formal learning environments in secondary chemistry classrooms. Impacts on teachers' professional development and curriculum innovation are also addressed.
\end{abstract}

\section{Introduction}

Today's society must deal with numerous challenges, including the growing scarcity of raw materials, increasing levels of environmental pollution, and climate change. These problems demand many scientific, ethical and political decisions within any democratic society. Students need to become skillful participants in these decisions in the future. Education needs to prepare learners by giving them the corresponding knowledge and developing appropriate skill sets (Hofstein, Eilks, \& Bybee, 2011). Students need to develop capabilities to act responsibly at the individual level, while at the same time gaining an understanding of how to contribute to societal debates on any emerging techno-scientific developments (Sjöström, Rauch, \& Eilks, 2015).

If we desire to enable students to deal with sustainable issues responsibly and to participate in today's society, a skills-oriented teaching paradigm, problem-based learning environments, and training in both science-related communication and societal decisionmaking processes are needed (Burmeister, Rauch, \& Eilks, 2012; Gresch, Hasselhorm, \& Bögeholz, 2013). By 1992, the Agenda 21 had already suggested education as the essential tool for achieving sustainability and referred to its key role in achieving a sustainable future (UNCED, 1992). Connecting science learning with environmental and sustainability issues 
can also promote the relevance of science learning and the students' perceptions thereof (Mandler, Mamlok-Naaman, Blonder, Yayon, \& Hofstein, 2012; Stuckey, Hofstein, MamlokNaaman, \& Eilks, 2013; Zeidler, Sadler, Simmons, \& Howes, 2005). Aspects of green chemistry (Karpudewan, Ismail, \& Mohammed, 2011) and chemistry-related socio-scientific issues (Burmeister \& Eilks, 2012) have been described as well-suited for integrating Education for Sustainable Development (ESD) into chemistry education. Unfortunately, research has revealed that thorough approaches to ESD can hardly be found in formal education in many countries and many educational domains. The reasons are multifaceted and range from insufficient teaching materials and a lack of adequate experiments to deficits in teacher education programs (Burmeister, et al., 2012; Burmeister, Schmidt-Jacob \& Eilks, 2013). This results in a lack of student understanding in sustainability issues such as climate change (Howard, Brown, Chung, Jobson, \& VanReken, 2013).

This article describes a project trying to overcome these problems. The purpose of the project "Sustainability and chemistry in non-formal student laboratories" was to develop and implement a new set of non-formal learning environments for secondary chemistry education focusing on ESD. The learning environments were created informed by educational theory and at the same time they were developed in an action research design process to match best teachers' and students' needs. The learning environments were cyclically developed in order to both develop science teaching via the non-formal educational domain, to contribute to curriculum innovation, as well as to in-service teachers' continuous professional development. The underlying framework for design orients itself along the model of Participatory Action Research as suggested by Eilks and Ralle (2002) for innovations in science education. In a first phase initial learning environments were structured according to reported deficits in practice. The learning environments were pretested with small groups of students. Classroom observations and feedback from students and teachers led to a process of cyclical optimization. In another phase the learning environments were tested with a growing number of learning groups before the learning environments were finally implemented.

\section{Quality in non-formal learning}

Hopkins and McKeowen (2002) stated that schools alone cannot shoulder education's overall responsibility for ESD. Non-formal and informal learning environments have also been suggested as working partners (Holbrook, 2009). Formal teaching in schools is structured, organized and follows a specific set of learning objectives. Informal learning is different from formal learning, because it has no given curriculum or structure and is not connected to any formal syllabus. In contrast to school-based learning, visiting a museum on the weekend belongs to informal learning. It is a voluntary task, informally organized, and takes place outside of school. Non-formal learning settings lie somewhere in between informal and formal learning. Non-formal learning is often rather organized than schooling settings, but can also have prescribed learning objectives. However, it takes place outside 


\section{IMPLEMENTING INNOVATIONS IN A NON-FORMAL STUDENT LABORATORY CONTEXT}

regular lessons and may even lie outside the school campus (OECD, 2012). As a link to formal learning, field trips to non-formal learning environments provide great learning chances, if the inner- and outer-school experiences are carefully linked to one another (Bybee, 2001). Orion and Hofstein (1994), Gallacher and Feutrie (2003), Braund and Reiss (2006), Rennie (2007) and Eshach (2007) have suggested several conditions, which need to be fulfilled in order to make optimal use of non-formal learning environments:

- The subject matter content needs to be covered in school before and after visiting the out-of-school learning environment. Otherwise there is a danger that students will not link the out-of-school experiences with formal learning.

- National syllabi should be met in order to bridge inner and outer school learning.

- Flexible and individually adaptable programs simplify the integration of out-ofschool learning activities with formal learning.

- The learning environment should be student-centered, inquiry-based, and interactive. Cooperative learning forms should be instituted.

- The working materials need to be adjustable to the current student's performance and knowledge level.

One type of non-formal educational settings for science education which has become very popular in recent years in Germany is the so called Schülerlabor(SL), non-formal laboratories established for primary and secondary science learning outside the schools (Hempelmann, 2014). These SLs are often located at universities, in research institutes, and in larger companies. The laboratories are well-equipped and are intended to support formal science learning. Primary and secondary school classes visit SLs with their teachers to conduct experiments during half- or full-day visits. The labs pay great attention to providing intensive experimentation. Thus, SLs and the lab activities in them are generally less structured than formal learning in school. Many have a particular domain of science or technology as a focal point around which various experimental courses are structured. However, these courses do not always coincide with the governmental syllabus or school curriculum. Originally, SLs were primarily founded to motivate students for careers in science and technology. However, in recent years SLs have also been acknowledged as a valuable place for supporting science teaching in schools for all, curriculum development, science teacher pre-service education, and in-service teachers' continual professional development (Garner, Hayes, \& Eilks, 2014). 


\section{The project "Sustainability and chemistry in non-formal student laboratories"}

\subsection{Background and scope}

The project "Sustainability and Chemistry in non-formal student laboratories" was initiated to create innovative teaching and learning environments, which focus on sustainability issues in chemistry-related contexts (Garner, Huwer, Siol, Hempelmann, \& Eilks, 2015). Three research groups at two German universities combined their expertise. These three partners consisted of the Institute of Science Education at the University of Bremen, the Institute for Environmental Research and Sustainable Technologies also at the University of Bremen, and the Department of Physical Chemistry at Saarland University. All of the project partners maintain well established SLs in Bremen and Saarbrücken. The project lasted from 2011 2014.

The first and central focus of this project was to help science teachers to overcome difficulties in conducting lab work on the topic of sustainability issues and green chemistry. The chosen fields are difficult to teach due to a lack of suitable laboratory equipment, high costs, and poorly-designed facilities in schools. Teachers who were interested in implementing these topics in their teaching were invited to visit the SLs with their students in Bremen and Saarbrücken, so that they could explore and evaluate the university laboratory learning environments. The objective was to make learning about sustainability and chemistry more practical, interactive and motivating. Also, the student laboratory was designed to introduce teachers to new subject matter content from the sustainability debate and green chemistry. This included making them familiar with new experiments, as well as teaching and learning materials, and encouraged teachers to take time for self-reflection as part of their personal, continuous, professional development (Garner et al., 2014).

\subsection{Design of the learning environments}

Within the project, several learning environments were developed and implemented in Bremen and Saarbrücken. The design and development was based on quality control suggestions for out-of-school learning environments as discussed above:

All contents need to be addressed in school before and after visiting an out-of-school learning environment.

All of the learning environments have a modular structure. Each module consists of three obligatory and one facultative part (Figure 1). A module starts with a preparation exercise, which is carried out prior to the SL visit. Based on an activity from the literature the teachers prepare their students in school to the upcoming visit to the SL. Such pre-visit contention with the topic has been recommended to raise the level of both student situational interest and personal motivation. Students are explicitly aware of the topic to be covered during the SL visit. The practical work in the laboratory is the core element of each module. The students 


\section{IMPLEMENTING INNOVATIONS IN A NON-FORMAL STUDENT LABORATORY CONTEXT}

conduct experiments autonomously in cooperative small groups with the support of university staff members. A further option is a follow-up of the practical lab work by an excursion to either a research laboratory or a relevant industrial facility. The modules end with suggestions for debriefing exercises, which teachers can use after returning to the classroom. Connecting the SL visit to pre- and post-visit activities avoids the danger that students may not connect the SL experience with their formal learning in school.

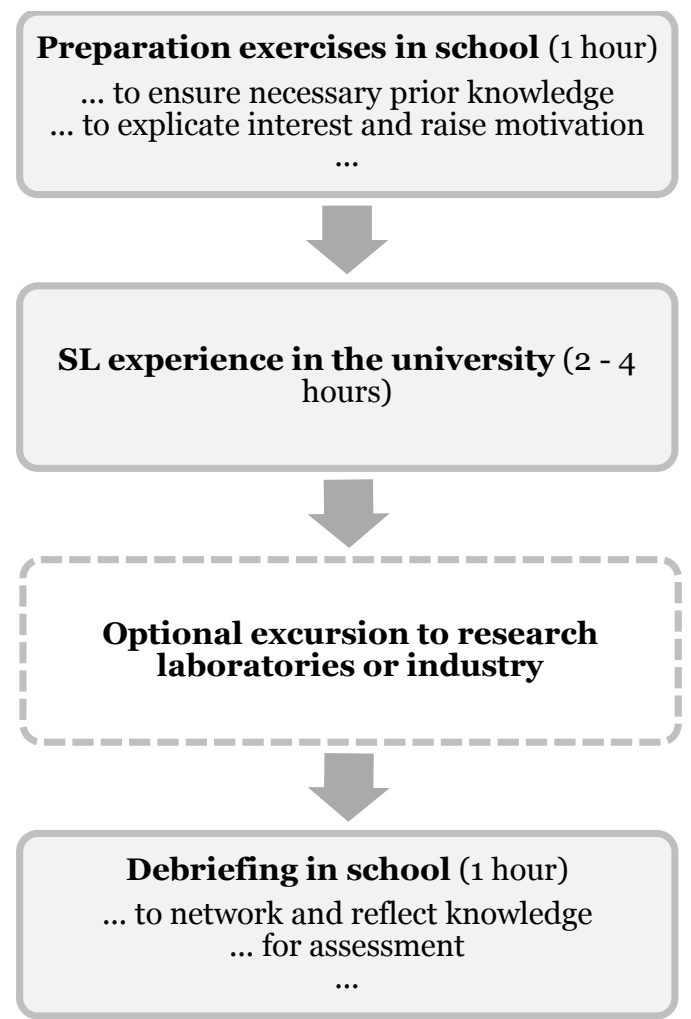

Figure 1. General construction of the teaching modules.

National syllabi should be addressed in order to link in-school and extracurricular learning. All of the topics have been selected to meet the core topics covered by the German national science education standards and the corresponding regional syllabi (Table 1). A total of 15 modules for grade 5-13 (age range 10-19 years) were developed and implemented in both SLs. The topics include the use of renewable raw materials, water treatment, the chemistry of the atmosphere, types of modern technology, and chemical synthesis strategies in industry. These are connected to typical German chemistry syllabi, e.g. matter and its properties, water, air and combustion, organic reactions, chemical equilibrium, and catalysts. All of the modules focus on different aspects of sustainability and sustainable chemistry. Depending on their age, students have to deal with aspects such as renewable materials, avoiding environmental pollution, the human influence on the atmosphere, modern chemical synthesis strategies, and green chemistry. The topics chosen in the SL at the University of Bremen ranged from the use of renewable raw materials to atmospheric pollution, biofuels, and modern technologies, and synthesis strategies in the chemical industry. The topics are embedded into meaningful contexts taken from the sustainability debate in the sense of 
situated cognition (Greeno, 1988). They also contain a socio-scientific focus to allow for general educational skills-oriented learning (Marks \& Eilks, 2009).

Table 1: Exemplary overview of the learning environments
Grade
Module
Aspect of sustainability

Learning environments developed by project partner Bremen

\begin{tabular}{|c|c|c|}
\hline $5^{\text {th }} / 6^{\text {th }}$ & Fragrances from flowers and fruits & $\begin{array}{l}\text { scarcity of resources / use of renewable } \\
\text { raw materials }\end{array}$ \\
\hline $7^{\text {th }} / 8^{\text {th }}$ & Chemistry of the atmosphere & Human influence on the planet \\
\hline $9^{\text {th }} / 10^{\text {th }}$ & Biodiesel produced from vegetable fats & $\begin{array}{l}\text { Renewable energy sources to protect } \\
\text { resources }\end{array}$ \\
\hline \multirow[t]{2}{*}{$11^{\text {th }}-13^{\text {th }}$} & Synthesis and analysis of vanillin & $\begin{array}{l}\text { Natural products, synthetic alternatives, } \\
\text { and assessment of different pathways for } \\
\text { industrial chemical production }\end{array}$ \\
\hline & $\begin{array}{c}\text { Zeolites and molecular sieves } \\
\text { Applications in industry and daily life }\end{array}$ & $\begin{array}{l}\text { Modern and sustainable synthesis } \\
\text { strategies }\end{array}$ \\
\hline
\end{tabular}

Learning environments developed by project partner Saarbrücken

\begin{tabular}{lcl}
\hline $5^{\text {th }} / 6^{\text {th }}$ & Water purification & Efficient use of limited resources \\
\hline $9^{\text {th }} / 10^{\text {th }}$ & Storage of electricity & Sustainable energy supply \\
\cline { 2 - 3 } & Corrosion and corrosion protection & Avoiding toxic chemicals \\
$11^{\text {th }}-13^{\text {th }}$ & Synthesis and analysis of aspirin & $\begin{array}{l}\text { Applications of Green Chemistry } \\
\text { principles in modern chemistry research } \\
\text { and industry }\end{array}$ \\
\cline { 2 - 3 } & Bioenergy - thermodynamic aspects & $\begin{array}{l}\text { Stewardship of resources and } \\
\text { comparison of different fuels. }\end{array}$ \\
\hline
\end{tabular}

Flexible and individually adaptable programs simplify the integration of out-of-school learning activities into formal learning. A large pool of experiments and instructions is offered to participants in each of the modules in order to ensure flexible, individual adaptability. Each module contains more experiments than students can possibly conduct during one laboratory session. Before the visit, teachers receive a handout with general information about the project and especially helpful background knowledge on the module topic. A brief overview of all the available experiments is given and master copies of worksheets and experiments are also provided in the packet. The teachers are asked to select the experiments which best fit their requirements, objectives, and the syllabus. The manual allows the teacher to prepare for implementing the module and to tailor a specific program for their respective learning group.

The learning environment should be student-centered, inquiry-based, and interactive. A student-orientated (Eilks, Prins, \& Lazarowitz, 2013), inquiry-based (Hofstein, Kipnis, \& Abrahams, 2013) approach is applied. Different levels of inquiry-based learning are used, which range from guided inquiry to open inquiry as discussed by Tafoya, Sunal, and Knecht (1980). Generally, the students are allowed to try out different solutions for any given task. This can and does lead to failures. This is always a risk in inquiry-based experimentation, but 


\section{IMPLEMENTING INNOVATIONS IN A NON-FORMAL STUDENT LABORATORY CONTEXT}

failures are considered to be an essential part of the learning process (Lunetta, Hofstein \& Clough, 2007). In order to support opportunities for failures, the experimental tasks are either very short or are split into single steps. This aids in adding time constraints and in avoiding a loss of learner motivation due to overlong phases.

The working materials need to be adjustable to the current student's performance and knowledge level. Based on the teacher guide, the teacher selects appropriate experiments for the visit with the help of SL staff members, including the level of inquiry with respect to the students' prior experiences, knowledge and skills. The teacher's manual covers any necessary foreknowledge which the students need to succeed. Teachers can therefore prepare their pupils for the starting point of the laboratory activities.

\subsection{One case in practice: Synthesis and analysis of vanillin}

A module named "Synthesis and analysis of vanillin" has been developed for students in upper secondary school (age range 16 - 19). This topic is known to every student, since vanilla flavoring is popular and used in many desserts, drinks, and perfumes. In the past, this flavoring agent was obtained largely from vanilla beans. The beans contain 1-3\% vanillin (4hydroxybenzaldehyde), which is the main component constituting vanilla flavor. The beans are grown mainly in Madagascar, the Comoros, and Reunion, then transported all over the world (etcGroup, 2012). Around 2,00o tons of natural vanilla are produced each year. However, capacities are limited and the demand for vanilla is continuously growing. This is why vanilla flavor is mainly produced synthetically today. Lignin, guaiacol, and occasionally clove oil have all been used as starting materials for producing artificial vanillin substitutes (Kalikar, Deshpande, \& Chandalia, 1986; Hocking, 1997; Lampman \& Sharpe, 1983). Artificial vanillin is much cheaper than natural vanilla. However, vanillin only forms part of the unique flavor mix making up natural vanilla, since its smell and taste is quite complex, containing about 100 aromatic components.

The module "Synthesis and analysis of vanillin" offers a maximum of seven experiments. The experiments range from different synthesis routes for vanillin to structural inquiries and the analysis of vanilla and vanillin in certain products (Table 2).

Table 2: Experiments for the module "Synthesis an analysis of vanillin"

Synthesis of vanillin:
E1a: Synthesis of vanillin from iso-eugenol (conventional)
E1b: Synthesis of vanillin from iso-eugenol (by microwave)
E2: Synthesis of vanillin from lignin
Analytical experiments:
E3 Comparison of natural vanilla flavor and artificial vanillin
E4 Detection of vanilla flavor and artificial vanillin in food
Structure enlightening experiments:
E5 Inquiring the molecular structure of vanillin
E6 Structure-property - relationship of aromatic fragrances

The connection to sustainability issues is made via the ideas of Green Chemistry. In 1998 Anastas and Warner established Green Chemistry as a regulative idea for sustainable development in chemistry research and for industry. Understanding the "greenness" of a 
synthesis can be done by comparing different synthetic routes. In this module, a conventional synthesis route to vanillin from iso-eugenol is compared with aspects of other modified syntheses. Aspects such as overall energy consumption, solvent use, waste production and effective yields can therefore be investigated and discussed.

As in all the other examples, all experimental instructions are made available to the teachers. Exercises and worksheets dealing with chemical background knowledge are provided, as is information covering societal issues involved with the topic. The applied principles of Green Chemistry are also explained for the preparation and debriefing exercises in school. During the SL experience, each student receives a research booklet containing all necessary worksheets. The booket also has space to record hypotheses, ideas, sketches, observations, and notes. The students are guided through the whole teaching module by this booklet. Implementation of the module started in December 2012. Up to the present 70 upper secondary level chemistry students have synthesized artificial vanillin in the SL.

\subsection{Accompanying research and selected findings}

The action research based development of the learning environments followed a cyclical process of design, testing, evaluation, and optimization. After each implementation, the modules were evaluated with two questionnaires for teachers and learners. The questionnaires consisted of Likert items and open questions. The data were collected in order to optimize the materials and to discover something about participants' prior expectations and post-laboratory experiences. In the first questionnaire, participants were asked about their expectations of the SL visit. In the second questionnaire, teachers and students were asked to describe their explicit experiences. All participants who joined SL modules in Bremen were asked to contribute in the surveys. The analysis of the open-ended questions was performed using qualitative content analysis according to Mayring (2010). The categories were communicatively validated and applied to the data by two independent raters. Reliability of the rating was very good. Data from the Likert items was evaluated statistically. A total of 461 students and 37 teachers have participated in the study so far.

Prior to the SL visit, less than $5 \%$ of the students expressed negative feelings about the upcoming experience. Many students hoped to be able to perform many experiments (69\%). A total of $35 \%$ of participants believed they would have a chance to work in better experimental conditions than they regularly experience in school. In particular, better equipment, more room to work, and more time with no pressure in achieving good marks were all mentioned. In addition to the practical expectations, almost $20 \%$ of students also expected to gain a deeper knowledge by attending the SL. Many students expressed very general expectations. They have never visited a SL and wanted to have new experiences (24\%) or they expected an offer that better fit their personal interests (17\%). The teachers had generally similar expectations of the SL. Almost 95\% expected the SL to offer opportunities for intense experimental work. About $75 \%$ of teachers also wanted the SL to supplement their own formal teaching in a meaningful way. In particular, it was seen as a chance providing 


\section{IMPLEMENTING INNOVATIONS IN A NON-FORMAL STUDENT LABORATORY CONTEXT}

experimental opportunities which are impossible or difficult to find in schools. The teachers hoped that the visit to the SL would enrich the lab work practices in their classes. They also listed time constraints, insufficient equipment, and overloaded curricula in the frame of their regular classes as problems. In addition to the specific expectations for pupil activity, another $20 \%$ of the teachers hoped for a certain relief in mentoring their students and in the timeintensive preparation for experimental work. Almost 70\% of the teachers expected an improved attitude among their students with respect to science and chemistry. Compared to their students, fewer teachers expected an increase in subject matter knowledge gains by students attending the SL (10\%). For the teachers, motivational aspects seemed to be more important than explicit knowledge gains. However, the teachers also expected advantages for their own teaching practices. $45 \%$ of the teachers hoped to gain new teaching and learning materials, as well as information about experiments that they could use in their own teaching. The teachers seem to receive input for their teaching, both in terms of content knowledge, and with respect to pedagogical content knowledge about suitable experiments, feasible teaching methods, and available learning materials. About half of the teachers expressed a willingness to use materials from the project in their own teaching. The findings from the open-ended questions were supported by the Likert items.

After visiting the SL, the majority of the participants were very satisfied with the offerings. $90 \%$ of the students and $100 \%$ of the teachers gave positive feedback. The students again stated the importance of autonomous and self-directed experimentation for their learning. Both students and teachers highlighted the helpful situation during the SL experience of having the university staff available. The teachers were constantly supported by at least two university staff members. Thereby, students' individual questions and needs could be given more attention. Students took this opportunity to ask a lot of questions. The teachers also emphasized that they had had an opportunity to observe their students from a different angle. In personal conversations, several teachers mentioned that their pupils' working behavior was much better than they had expected.

\section{Conclusion}

This project shows an opportunity to link in-school and extracurricular learning. Aspects such as inadequate lab equipment, poor working conditions and the ever-present time factor all hinder experimental work in formal learning situations. Accordingly, participants expect SL to offer broad experimental experiences. Non-formal SLs can enrich science education by implementing experimental practices which are hardly feasible in school settings. However, SLs should not being used as an excuse to reduce the amount of practical work in schools even further.

The teachers had hoped for an improvement in terms of student motivation and attitudes towards science and chemistry education. The feedback from the SL participants indicates that SLs have the potential to enhance students' attitudes and motivation towards chemistry and science education, at least on a situational basis. This was also reported in Orion and 
Hofstein (1991), who claimed that informal and non-formal learning environments could foster a more positive student attitude towards learning science. But research has also shown that motivational effects are often short-lived or middle-term effects. Lasting positive effects could be detected only with regular visits, including a close connection of non-formal and formal learning environments (DeWitt \& Storksdiek, 2008; Wolins, Jensen, \& Ulzheimer, 1992).

There are also indications that SLs provide opportunities to expose teachers to and familiarize them with new content, innovative experiments, and teaching and learning materials. Nearly half of the teachers stated to be interested in integrating both SL learning as well as issues of sustainability into their own classrooms. Thus, SLs represent a great opportunity to come into contact with new content and curriculum materials from the teachers' point of view. In addition, the teachers followed their students' behavior during the laboratory session with great interest. This may offer a chance to reflect upon the materials, experiments and their own learners with respect to normal classroom experiences in school. Accompanying university staff members may support this process by targeted assistance. From this perspective, there is hope that the current project has helped implement ESD in formal science education, at least to a certain extent (Garner, et al., 2014). Further research might now focus in more detail to whether and how the developed learning environments also contribute to cognitive gains in the field of green chemistry knowledge and understanding, as well as educational skill development in terms of ESD.

\section{Acknowledgements}

We are grateful acknowledge the financial support for the project by the Deutsche Bundesstiftung Umwelt (DBU). 


\section{IMPLEMENTING INNOVATIONS IN A NON-FORMAL STUDENT LABORATORY CONTEXT}

\section{References}

Anastas, P. T., \& Warner, J. C. (1998). Green Chemistry: Theory and practice. Oxford, UK: Oxford University Press.

Burmeister, M \& Eilks I. (2012). An example of learning about plastics and their evaluation as a contribution to Education for Sustainable Development in secondary school chemistry teaching. Chemistry Education Research and Practice, 13, 93-102. doi: 10.1039/C1RP90067F

Burmeister, M., Rauch, F., \& Eilks, I. (2012). Education for Sustainable Development (ESD) and chemistry education. Chemistry Education Research and Practice, 13, 59-68. doi: 10.1039/C1RP90060A

Burmeister, M., Schmidt-Jacob, S., \& Eilks, I. (2013). German chemistry teachers' understanding of sustainability and education for sustainable development - An interview case study. Chemistry Education Research and Practice, 14, 169-176. doi: 10.1039/C2RP20137B

Braund, M., \& Reiss, M. (2006). Towards a more authentic science curriculum: The contribution of out-of-school learning. International Journal of Science Education, 28, 1373-1388. doi: 10.1080/09500690500498419

Bybee, R. W. (2001). Achieving scientific literacy: Strategies for insuring that free-choice science education complements national formal science education efforts. In H. J. Falk (Ed.), Free-choice science education: How we learn science outside of school (pp. 44-63). New York, NY: Teachers College Press.

DeWitt, J., \& Storksdieck, M. (2008). A short review of school field trips: Key findings from the past and implications for the future. Visitor Studies, 11, 181-197. doi: 10.1080/10645570802355562

Eilks, I., \& Ralle, B. (2002). Participatory Action Research in chemical education. In B. Ralle \& Eilks, I. (Eds.), Research in Chemical Education - What does this mean? (pp. 87-98). Aachen, Shaker.

Eilks, I. (2014). Action research in science education: From a general justification to a spe- cific model in practice. In T. Stern, F. Rauch, A. Schuster, \& A. Townsend (Eds.), Action research, innovation and change (pp. 156-176). London: Routledge.

Eilks, I., Prins, G. T., \& Lazarowitz, R. (2013). How to organise the chemistry classroom in a studentactive mode. In I. Eilks \& A. Hofstein (Eds.), Teaching chemistry - A studybook (pp. 183-212). Rotterdam: Sense.

Eshach, H. (2007). Bridging in-school and out-of-school learning: formal, non-formal, and informal education. Journal of Science Education and Technology, 16, 171-190. doi: 10.1007/s10956-0069027-1

etcGroup (2012). Synthetic Biology: Livelihoods and Biodiversity - Vanilla. Retrieved from http://www.etcgroup.org/files/CBD_Vanilla_case_study_TA.pdf.

Gallacher, J., \& Feutrie, M. (2003). Recognising and accrediting informal and non-formal learning in higher education: An analysis of the issues emerging from a study of France and Scotland. European Journal of Education, 38, 71-83. doi: 10.1111/1467-3435.00129

Garner, N., Hayes, S. M., \& Eilks, I. (2014). Linking formal and non-formal science education - A reflection from two cases in Ireland and Germany. Sisyphus Journal of Education, 2(2), 10-31. Retrieved from http://www.revistas.rcaap.pt/sisyphus.

Garner, N., Huwer, J., Siol, A., Hempelmann, R., \& Eilks, I. (2015). On the development of nonformal learning environments for secondary school students focusing sustainability and Green Chemistry. In V. Gomes Zuin \& L. Mammino (Eds.), Worldwide trends in green chemistry education. Cambridge, UK: RSC (in press).

Greeno, J. G. (1988). Situations, mental models, and generative knowledge. In D. Klahr \& K. Kotovsky (Eds.), Complex information processing: The impact of H. A. Simon (pp. 285-318). Hillsdale, MI: Lawrence Erlbaum.

Gresch, H., Hasselhorn, M., \& Bögeholz, S. (2013). Training in Decision-making Strategies: An approach to enhance students' competence to deal with socio-scientific issues, International Journal of Science Education, 35, 2587-2607. doi: 10.1080/09500693.2011.617789

Hempelmann, R. (2014). Schülerlabors and sustainability. In I. Eilks, S. Markic, \& B. Ralle (Eds.) Science education research and education for sustainable development (pp. 189-197). Aachen: Shaker. 
Hocking, M. B (1997). Vanillin: Synthetic flavoring from spent sulfite liquor. Journal of Chemical Education, 74, 1055-1059. doi: 10.1021/edo74p1055

Hofstein, A., Eilks, I., \& Bybee, R. (2011). Societal issues and their importance for contemporary science education: a pedagogical justification and the state of the art in Israel, Germany and the USA. International Journal of Science and Mathematics Education, 9, 1459-1483. doi: 10.1007/s10763-010-9273-9

Hofstein, A., Kipnis, M., \& Abrahams, I. (2012). How to learn in and from the chemistry laboratory. In I. Eilks \& A. Hofstein (Eds.), Teaching chemistry - A studybook (pp. 153-282). Rotterdam: Sense.

Holbrook, J. (2009). Meeting challenges to sustainable development trough science and technology education. Science Education International, 20(1), 44-59. Retrieved from http://www.files.eric.ed.gov /fulltext/EJ890655.pdf

Hopkins, C., \& McKeown, R. (2002). Education for Sustainable Development: An international perspective In D. Tilbury, R. B. Stevenson, J. Fein, D. Schreuder (Eds), Environmental education for sustainability: Responding to the global challenge, Gland: IUCN Commission on Education and Communication.

Howard, K. E., Brown, S. A., Chung, S. H., Jobson, B. T., \& VanReken, T. M. (2013). College stutends `understanding of atmospheric ozone formation. Chemistry Education Research and Practice, 14, 51-61. doi: 10.1039/C2RP20074K

Kalikar, R. G., Deshpande, R. S., \& Chanadlia, S. B. (1986). Synthesis of vanillin and 4 hydroxybenzaldehyde by a reaction scheme involving condensation of phenols with glyoxylic acid, Journal of Chemical Technology and Biotechnology, 36(1), 38-46. doi: 10.1002/jctb.280360107

Karpudewan, M., Ismail, Z. H., \& Mohamed, N. (2011). Green Chemistry: Educating prospective science teachers in education for sustainable development at school of educational studies. Journal of Social Sciences, 7, 42-50. doi: 10.3844/jssp.2011.42.50

Lampman, G. M., \& Sharpe, S. D. (1983) A phase transfer catalyzed permanganate oxidation. Journal of Chemical Education, 6o, 503-504. doi: 10.1021/edo6op503

Lunetta, V. N., Hofstein, A., \& Clough, M. P. (2007). Learning and teaching in the school science laboratory: An analysis of research, theory and practice. In S. Abell \& N. Lederman (Eds.), Handbook of Research on Science Education (pp. 393-441), Mahwah, NJ: LEA Publishers.

Mandler, D., Mamlok-Naaman, R., Blonder, R., Yayon, M., \& Hofstein, A. (2012). High School chemistry teaching through environmentally oriented curricula. Chemistry Education Research and Practice, 13, 80-91. doi: 10.1039/C1RP90071D

Marks, R., \& Eilks, I. (2009). Promoting scientific literacy using a socio-critical and problem-oriented approach to chemistry teaching: concept, examples, experiences. International Journal of Environmental \& Science Education, 4, 231-245.

Mayring, P. (2010). Qualitative Inhaltsanalyse - Grundlagen und Techniken [Qualitative content analysis - fundamentals and techniques]. Weinheim: Beltz.

OECD (2012). Higher education and adult learning - Recognition of Non-formal and Informal Learning. Retrieved from http://www.oecd.org/edu/skills-beyond-school/recognitionofnonformalandinformallearning-home.htm.

Orion, N., \& Hofstein, A. (1991). The measurement of students' attitudes towards scientific field trips. Science Education, 75, 513-523. doi: 10.1002/sce.3730750503

Orion, N., \& Hofstein, A. (1994). Factors that influence learning during a scientific field trip in a natural environment. Journal of Research in Science Teaching, 31, 1097-1119. doi: 10.1002/tea.3660311005

Rennie, L. J. (2007). Learning science outside of school. In S. Abell \& N. Lederman (Eds.), Handbook of Research on Science Education (pp. 125-170), Mahwah, NJ: LEA Publishers.

Sjöström, J., Rauch, F., \& Eilks, I. (2015). Chemistry education for sustainability. In I. Eilks \& A. Hofstein (Eds.), Relevant chemistry education - from theory to practice (pp. 163-184).

Rotterdam: Sense. 


\section{IMPLEMENTING INNOVATIONS IN A NON-FORMAL STUDENT LABORATORY CONTEXT}

Stuckey, M., Mamlok-Naaman, R., Hofstein, A., \& Eilks, I. (2013). The meaning of 'relevance' in science education and its implications for the science curriculum. Studies in Science Education, 49, 1-34. doi: 10.1080/03057267.2013.802463

Tafoya, E., Sunal, D., \& Knecht, P. (1980). Assessing enquiry potential: A tool for curriculum decision makers. School Science and Mathematics, 8o, 43-48. doi: 10.1111/j.1949-8594.1980.tbo9559.x

UNCED (1992). Agenda 21. Retrieved from http://www.sustainabledevelopment.un.org/ content/documents/Agenda21.pdf.

Zeidler, D., Sadler, T., Simmons, M., \& Howes, E. (2005). Beyond STS: a research-based framework for socio-scientific issues education, Science Education, 89, 357-376. doi: 10.1002/sce.20048

Wolins, I. S., Jensen, N., \& Ulzheimer, R. (1992) Children's memories of museum field trips: A qualitative study. Journal of Museum Education, 17(2), 17-27. Retrieved from http://www.jstor.org/stable/ 40478925. 